\title{
SAMBUTAN
}

\section{KETUA JURUSAN SOSEK PERTANIAN UNSRAT}

Selamat Hari Ulang Tahun yang kedua bagi Jurnal Ilmiah Agrisosioekonomi Unsrat versi baru. Jurnal ilmiah Agrisosioekonomi ini merupakan Jurnal Ilmiah yang diterbitkan oleh Jurusan Sosial Ekonomi Pertanian, Fakultas Pertanian, Universitas Sam Ratulangi Manado. Jurnal ini diharapkan dapat mengambarkan tingkat produktivitas karya tulis ilmiah di bidang penelitian sosial-ekonomi pertanian maupun pertanian yang ditulis dari berbagai latar belakang atau kalangan termasuk para staf pengajar, mahasiswa baik mahasiswa S1 maupun S2, maupun peneliti dari berbagai lembaga penelitian terkait. Agar setiap hasil penelitian dan gagasan pembangunan dapat diinformasikan ke masyarakat ilmiah dan pengambil kebijakan.

Setelah dua tahun terbit dalam bentuk baru secara reguler dan kontinu terdapat berbagai perkembangan yang positif antara lain peningkatan dalam hal jumlah artikel dan penulis. Penulis yang datang dari berbagai latar belakang baik sebagai Staf Pengajar Unsrat maupun di luar Unsrat; Mahasiswa S-1 dan S-2 Unsrat yang juga adalah staf pemerintah daerah, antara lain, berasal dari Maluku Utara, Halmahera Utara, Papua Barat, Sulawesi Tengah, Minahasa Selatan, Bolaang Mongondow dan Kota Bitung; peneliti dari lembaga penelitian di luar Unsrat (Gorontalo). Proses penerbitan jurnal ilmiah ini juga merupakan wadah untuk belajar dan magang yang telah melibatkan sekitar delapan orang mahasiswa dan Alumni Baru dari Jurusan Sosek Pertanian Unsrat.

Pada kesempatan ini, saya sebagai Ketua Jurusan Sosek Pertanian, Fakultas Pertanian Unsrat mengucapkan banyak terima kasih kepada berbagai pihak yang telah terlibat dan membantu sehingga jurnal ini dapat terbit berkesinambungan. Penghargaan dan ucapan terima kasih terutama ditujukan kepada Tim Redaksi beserta Staf Redaksi untuk segala kerja kerasnya sehingga jurnal ilmiah ini dapat diterbitkan.

Ketua 